\title{
Development and Performance Evaluation of Groundnut Digger Elevator cum Heap Formater
}

\section{Kavad Anil1, Yadav Rajvir ${ }^{2 *}$, Vala Vimal ${ }^{3}$, Chavda Dipesh ${ }^{4}$ and Vagadia Vinay $^{4}$}

${ }^{1} \mathrm{M}$ Tech Farm Machinery \& Power, Junagadh Agricultural University, India

${ }^{2}$ Professor \& Head \& Department of Farm Engineering, College of Agriculture, Junagadh Agricultural University, India

${ }^{3}$ Ph.D. student, Farm Machinery \& Power, Junagadh Agricultural University, India

${ }^{4}$ Assistant Professor, Department of Farm Engineering, College of Agriculture, Junagadh Agricultural University, India

*Corresponding author: Rajvir Yadav, Professor \& Head, Department of Farm Engineering, College of Agriculture, Junagadh Agricultural University, Junagadh-362001,Gujarat, India, Email: ryadav61@gmail.com

\section{Abstract}

Groundnut (Archis hypogaea L) or peanut is a major oilseed crop which contributes 40 per cent of the total area and 30 per cent of total production of oilseed crops. In India among the major groundnut growing states, Gujarat is the most important one accounting for $36 \%$ of the total area. The groundnut digger elevator cum heap formater was developed considering various theories related to digger, elevator and heap formater assembly, agronomical parameters of groundnut, functional requirement and general consideration. The main components such as main frame, digging blade, elevator and heap assembly were developed. The developed groundnut digger elevator cum heap formater was able to dig up the groundnut plants with pods and convey them for removing the soil from pods and making heap. The experimental results showed the depth of cut of groundnut digger elevator cum heap assembly was found as $13.00 \mathrm{~cm}$, while width of coverage measure as $60 \mathrm{~cm}$ and moisture content (d.b.) of $19.20 \%$. The draft requirement of $235 \mathrm{kgf}$ and power requirement was calculated $7.83 \mathrm{hp}$ with fuel requirement of $2.04 \mathrm{l} / \mathrm{h}$. The theoretical field capacity of digger elevator cum heap formater was $0.12 \mathrm{ha} / \mathrm{h}$ while effective field capacity was $0.0935 \mathrm{ha} / \mathrm{h}$ with field efficiency of $80.47 \%$. The digging efficiency were found as $84.18,85.23$ and $86.36 \%$ at the forward speed of $1.5,2.0$ and $2.5 \mathrm{~km} / \mathrm{h}$ respectively. The total quality of pod was found $176.41,180.21$ and $173.91 \mathrm{gm}$ and pod damage percentage was found 4.37, 4.36 and $4.73 \%$ at forward speed of $1.5,2.0,2.5 \mathrm{~km} / \mathrm{h}$. The cost of harvesting by developed digger cum heap formater was found to be ₹ $371.98 / \mathrm{h}$.

Keywords: Groundnut; Digger; Elevator; Heap Formatter; Digging Blade; Field Efficiency

\section{Introduction}

Groundnut is an important oilseed crop in India cultivated in an area of 3.8 Mha with a production of 5.1 MMt annually. Gujarat state shares about $37.7 \%$ of groundnut area of the country and occupies 1st position production in the country. Groundnut is cultivated one of major oilseed crop in Gujarat. In Gujarat, Junagadh district first ranks in production of groundnut with 0.23 Mha and 0.31 MMt respectively in 2018 [1]. The best soils for groundnut crop are sandy loam, loam and medium black with a good drainage system. The mechanical soil tillage operations are performed using force, commonly by using a tractor drawn tool to achieve cutting, inversion, pulverization and movement of the soil Jakasania, et al. [2]. 
A groundnut digger was developed at CAET, JAU, Junagadh and was tested for its performance at the research farm of oil seed, JAU, Junagadh. This study was developed groundnut digger elevator cum heap formater to increase its performance under field conditions. The objectives of the study were to develop of groundnut digger elevator cum heap formater, to perform field test to assess its performance under practical conditions and to evaluate economics of the tractor operated ground nut digger elevator cum heap formater.

Stalker [3] studied the pod is an elongated sphere with different reticulation on the surface and constriction between the seeds, and contains one to five. Pods reach maximum size after 2 to 3 weeks in the soil, maximum oil content in 6 to 7 weeks, and maximum protein content after 5 to 8 weeks. Considerable variability exists in groundnut morphological traits: seed size, (0.15 to $1.3 \mathrm{~g} / \mathrm{seed}$ ), seed colour (white, light rose, rose, red, purple, white blotched with purple red), number of seeds/pod (1-5), pod length (11-83 mm), depth of groundnut pod is 80 to $100 \mathrm{~mm}$, pod breadth (9-27 mm).

Smyth [4] reported that harvesting techniques were also important in determining the milling quality of groundnut. In most of the developing countries harvested plants are left as such for drying in the field necessary for reducing losses from rotting, termites and moulds. A survey in Australia concluded that loss in manual harvesting method was 1020 $\%$, whereas by mechanical harvesting of pods losses $3 \%$ in digging and $5 \%$ during lifting, estimated by the USDA.

Nautiyal, et al. [5] concluded pod loses during harvesting were substantial (20 to 30\%). However the losses were more in the Virginia than the Spanish types. The harvesting losses were dependent on the method of harvest and soil moisture content at the time of harvest damage the crop quality. On the other hand soil moisture deficiency may increase the pad losses. Therefore, after reaching to the physiological maturity irrigation must be stopped. But at the same time it may also be insured that at the time of digging the soil moisture content in the field is optimum. Soil moisture at the time of digging is most important both to reduce the pod losses due to poor peg strength especially in Virginia types.

Afshin, et al. [6] studied the performance evaluation of a walking type tractor drawn peanut harvester and compared it with manual harvesting in Iran at different conditions of soil moisture content $(24.79 \%, 21.06 \%, 20.55 \%)$ and forward speeds $(1.7,2.5$ and $3.3 \mathrm{~km} \mathrm{~h}-1)$. Results revealed that the effect of soil moisture content $(24.79 \%)$ was only significant on the per cent of unexposed pods loss, while the effect of forward speed was not significant for damaged pods loss, exposed pods loss, unexposed pods loss and undug pods loss. Usage of mechanical harvesting instead of manual harvesting reduced the harvesting loss and harvesting costs.

Mohanty, et al. [7] developed and tested a sweep type groundnut digger in the experimental plot for finding its suitability. The machine was tested for digging of bunch variety AK- 1224 of groundnut. The test parameters were power requirement, field capacity, field efficiency, pod loss and digging efficiency. The field performance was compared with CIAE Bhopal model and found better in all respects. Its power requirement was less $(0.61 \mathrm{hp})$ as compared to CIAE Bhopal model $(0.94 \mathrm{hp})$. Its field capacity was $0.132 \mathrm{ha} / \mathrm{h}$ with a field efficiency of $70 \%$ at an operating speed of 1.59 $\mathrm{km} / \mathrm{h}$. It performed harvesting operation with total pods loss of $13.27 \%$ and a digging efficiency of $86.73 \%$. The cost of operation with this digger was Rs. 203.80/ha.

Mishra [8] developed a ridger type bullock drawn groundnut digger and tested for power requirement, effective field capacity, field efficiency, labour requirement and pod losses in coastal Orissa. The average draft and power requirement of the digger were observed to be $57 \mathrm{kgf}$ and $0.39 \mathrm{hp}$, respectively which were within the capacity of an average pair of bullock. The maximum digging efficiency of $91.8 \%$ was found under an optimum speed of $1.9 \mathrm{~km} / \mathrm{h}$. The cost of operation in case of manual digging was found to be Rs. $1100 /$ ha as compared to Rs. 653.40 /ha for this digger. The performance of this bullock drawn groundnut digger was satisfactory, economical and within the reach of small and marginal farmers growing groundnut crop on a commercial basis.

Jaiswal, et al. [9] developed digger cum shaker and operated in the field satisfactorily. The depth of cut of groundnut digger-cum-shaker was found as $13 \mathrm{~cm}$, while width of coverage measured as $60 \mathrm{~cm}$. The draft requirement of $201 \mathrm{~kg}$ at a speed of operation $2.41 \mathrm{~km} / \mathrm{h}$ and power requirement was $1.90 \mathrm{hp}$ with fuel consumption of 2.71 lit/h. The field efficiency was found promising in case of the developed groundnut digger-cum shaker.

Gabir and Ahmed [10] studied on different groundnut digging blades. The performance of four types of peanut digging blades, namely; flat-type, curved type, V-shaped type and double discs were evaluated. The results show that there was a difference in the degree of soil disturbed by the diggers. The percentage of soil disturbed decreased according to the shape of diggers used, namely; V-shaped, flat, curved and double discs, respectively. The results show that the V-shaped type had lower average draft force for increasing digging depths at both inclined angles of $0^{\circ}$ and $40^{\circ}$ compared to other digger types. For design of simplicity the V-shaped digger type was the best, and should be used as a digging blade in peanut harvesting machine. 


\section{Materials and Methods}

\section{Agronomical Considerations of Groundnut}

The bunch type variety of groundnut is commonly sown at row spacing of $30 \mathrm{~cm}$. The depth of groundnut pod is 8 to 10 $\mathrm{cm}$ in all types of groundnut varieties. The pod distribution zone below the ground is 16 to $20 \mathrm{~cm}$ on both sides of plant. The average height of groundnut crop is normally 20 to $25 \mathrm{~cm}$ above the ground surface. The maturity of groundnut crop is likely to happen generally 100 to 120 days after sowing in all types varieties.

\section{Design Consideration of Development of Groundnut Digger Elevator cum Heap Formater Operated by Mini tractor}

The digging blade in the groundnut digger digs the plant out of the soil along with the pods. The standard serves as a support tool to mount the digging blade of the groundnut digger. The conveyor helps to convey the dugout plants from the soil, shakes loose the adhering soil and conveys it to the back of the machine for deposition on the harvested ground in a row. The conveyor runs on two pairs of chain pulleys, which derive their drive from the power, transmitted from the tractor PTO to the implement. The conveyor consists of cross bars and on each bar seven picker pegs are provided at equal width wise spacing, which pick the dugout groundnut vines with pods. The ends of pegs are provided with a forward angle so that the picked plants do not fall from the conveyor while being conveyed. The machine consists of a pair of support wheels on the back which along with the hydraulic system of the tractor which controls the depth of operation. The conveying unit is followed by a heap formeter unit which helps in heap the dugout plants in a row behind the machine. Conceptual Model of the machine shown in Figure 1.

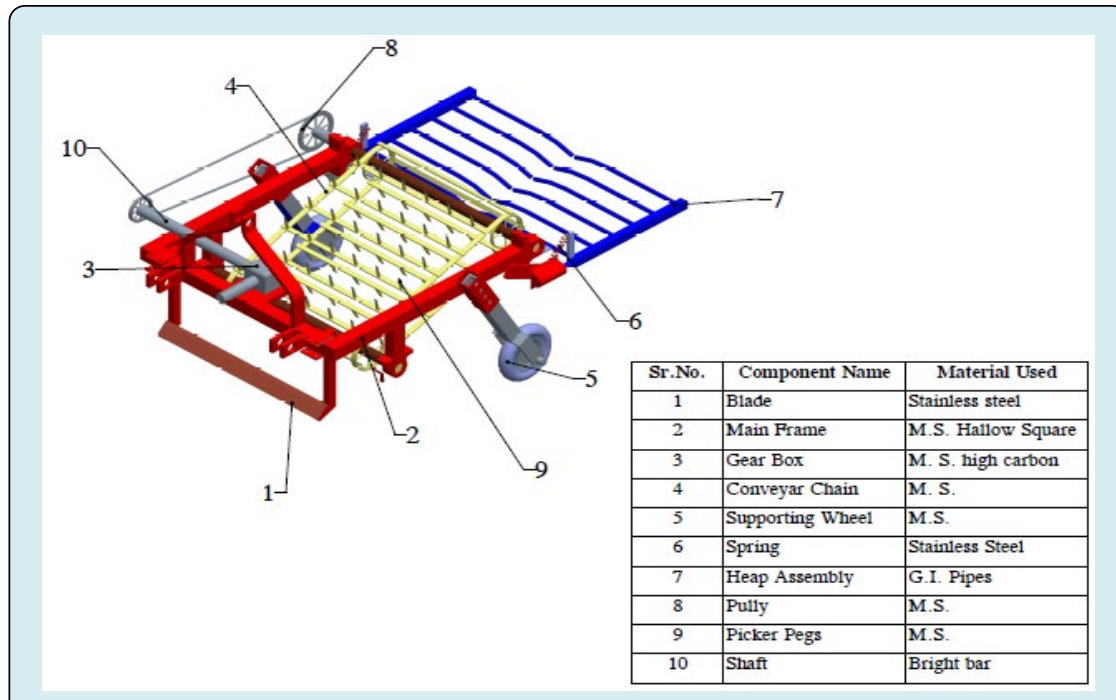

Figure 1: Conceptual model of the machine.

\section{Main Frame}

The components of the mount on the main frame (chassis) which is supported by two bars on the machine. The machine was connecting to the rigid hitch point of the prime-mover. Mostly hollow square frames made up of mild steel are used.

\section{Digging Blade}

Many of researchers did a lot of study on the blades suitable for groundnut digging. Based on reviews and considering general practice followed by the farmers in the region, flat shapes of blade (Figure 2).

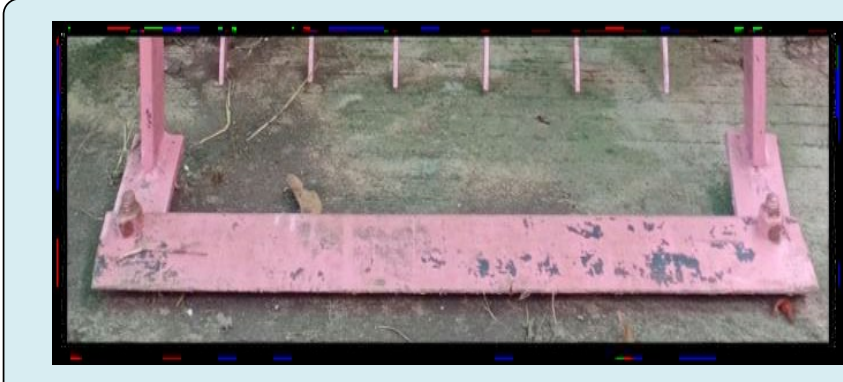

Figure 2: Fabricated blade.

\section{Elevator}

An elevator conveys the material from blade to the heap assembly. Its main function was to drop the maximum 
amount of soil mass and convey dig out groundnut to the heap assembly with minimum dropping and without damaging of the groundnut pods. It was made, from iron equally peg bars and small pegs at alternate positions. These pegs were welded on the conveyor to minimize the crop slippage. The iron bars were joined on chain with nut bolt. Four numbers of sprockets were mounted on the driver shaft of the elevator which rotates the elevator. All shafts were supported on pedestal bearings at both of ends for smooth and frictionless movement on it. By this arrangement, center to center distance between driver (upper side) and driven (lower side) shaft of elevator could be reduced at the time of mounting the conveyer on sprockets and rollers and the distance between shaft could be increased to get proper tension at the time operating the elevator (Figure 3 ).

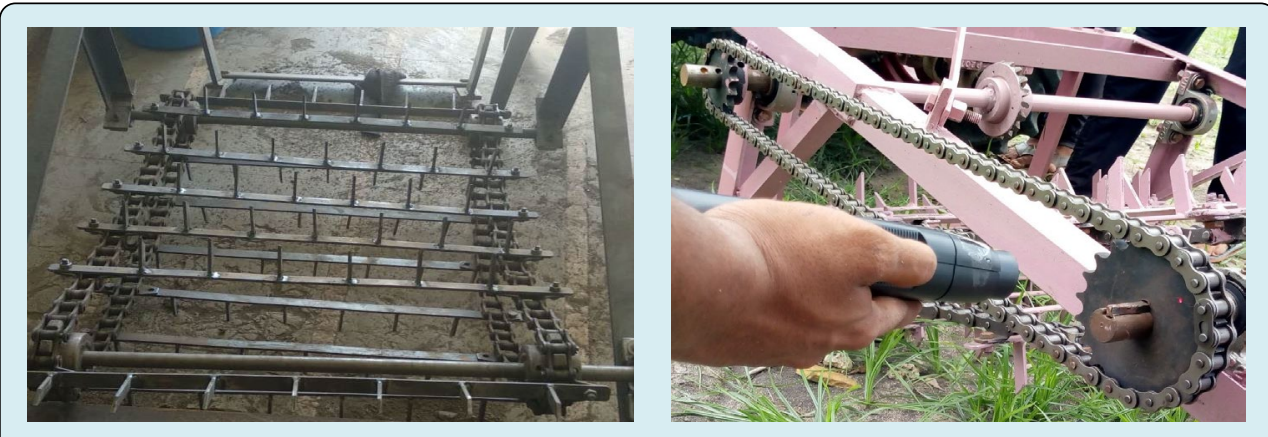

Figure 3: Fabricated elevator and power transmission.

\section{Heap Assembly}

Heap assembly will be used to collect groundnut and making heap formation at certain distance. To provided 6 iron rod both side and attached to spring with main frame. One revolution of conveyor was completed to push the plate at provided at one iron bar.

\section{Statistical Analysis}

Statistical analysis will be done by Complete Randomized Design (CRD) method in which the effect of various treatments on various parameters will be analysed.

\section{Results and Discussion}

\section{Field Efficiency of Groundnut Digger Elevator cum Heap Formatter}

The field efficiency of the developed groundnut digger elevator cum heap was determined as $80.47 \%$. The overall performance of the groundnut digger elevator cum heap formater is depicted in Table 1.

\begin{tabular}{|c|c|c|c|c|c|c|c|c|}
\hline Source & DF & SS & MSS & CAL F & TAB F & TEST & SEM & CD \\
\hline Treat & 2 & 599.384 & 299.692 & 96.457 & 3.554 & $* *$ & 0.667 & 1.979 \\
\hline Error & 18 & 55.926 & 3.106 & & 2.988 & & \\
\hline TOTAL & 20 & 655.310 & CV $\%=0.3128$ & & & & \\
\hline
\end{tabular}

Table 1: ANOVA showing effect of forward speed on field efficacy.

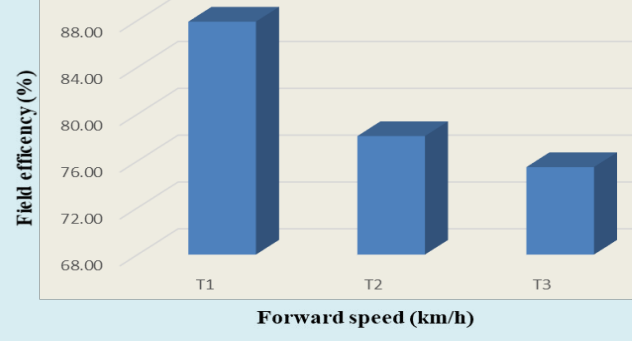

Figure 4: Graphical representation of field efficiency Vs forward speed.
From the results presented in Figure 4, it can be seen that as forward speed increases, the field efficiency also decreases. Higher field efficacy (87.90\%) was observed at $1.5 \mathrm{~km} / \mathrm{h}$ forward speed.

\section{Digging Efficacy}

ANOVA Table 2 shows that the speed of operation affected highly significantly on digging efficiency at 5 per cent and 1 per cent level. 


\begin{tabular}{|c|c|c|c|c|c|c|c|c|}
\hline Source & DF & SS & MSS & CAL F & TAB F & TEST & SEM & CD \\
\hline Treat & 2 & 16.663 & 8.331 & 14.309 & 3.554 & $* *$ & 0.288 & 0.856 \\
\hline Error & 18 & 10.481 & 0.582 & & 2.989 & & & \\
\hline TOTAL & 20 & 27.144 & \multicolumn{7}{|c|}{ CV $\%=0.1278$} \\
\hline
\end{tabular}

Table 2: ANOVA showing effect of forward speed on digging efficiency.

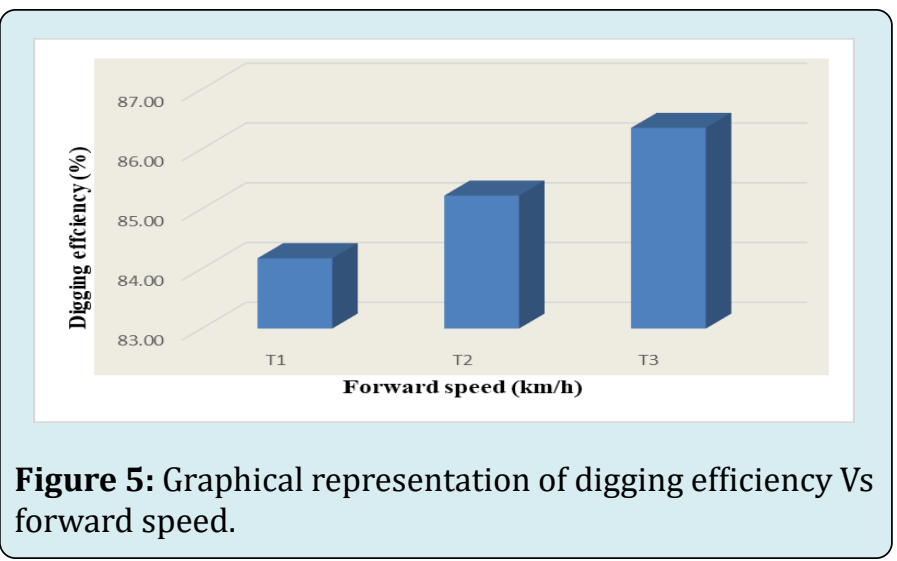

Figure 5 showed that the digging efficiency were increased from forward speed 1.5 to $2.5 \mathrm{~km} / \mathrm{h}$. The digging efficiency were found as $84.18,85.23$ and $86.36 \%$ at the forward speed of 1.5, 2.0 and $2.5 \mathrm{~km} / \mathrm{h}$ respectively and similar results were also obtained by Vagadia, et al. [11], Mehta, et al. [12] for onion harvesting, Solanki \& Yadav [13] for caster uprooting.

\section{Total Quality of Pod}

ANOVA Table 3 shows that the speed of operation affected highly significantly on cutting efficiency at 5 per cent and 1 per cent level.

The groundnut total quality of pod were found as 176.41, 180.21 and $173.91 \mathrm{gm}$ at forward speed of 1.5, 2.0 and 2.5 $\mathrm{km} / \mathrm{h}$ respectively shown in Fig. 6 . It might be due to rate of soil and groundnut mass coming on the conveyer would be increased with increase in the forward speed which would increase the friction between groundnut and clods ultimately causing more crushing of groundnut at higher speeds.

\begin{tabular}{|c|c|c|c|c|c|c|c|c|}
\hline Source & DF & SS & MSS & CAL F & TAB F & TEST & SEM & CD \\
\hline Treat & 2 & 140.887 & 70.443 & 14.188 & 3.554 & $* *$ & 0.8421 & 2.5022 \\
\hline Error & 18 & 89.366 & 4.964 & & 2.988 & & & \\
\hline TOTAL & 20 & 230.252 & \multicolumn{7}{|c|}{ CV $\%=0.1799$} \\
\hline
\end{tabular}

Table 3: ANOVA showing effect of forward speed on total quality of pod.

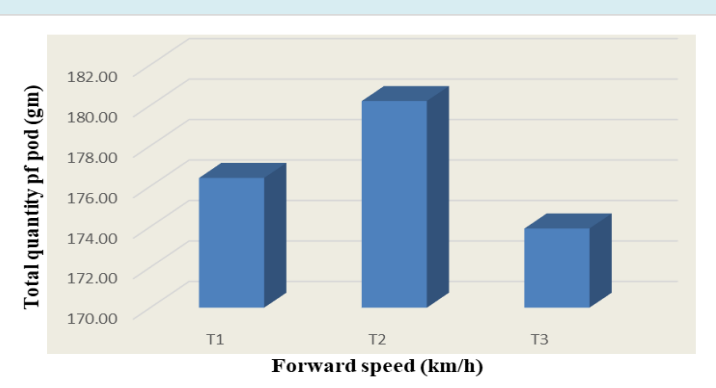

Figure 6: Graphical representation of total quality of pod Vs forward speed.

\section{Pod Damage Percentage}

ANOVA Table 4 shows non-significant effect of the speed of operation on pod damage percentage at 5 per cent and 1 per cent level.

The percentages of damaged groundnut were found as 4.37 , 4.36 and $4.73 \%$ at forward speed of $1.5,2.0$ and $2.5 \mathrm{~km} / \mathrm{h}$ respectively and depicted in Figure 7.

\begin{tabular}{|c|c|c|c|c|c|c|c|c|}
\hline Source & DF & SS & MSS & CAL F & TAB F & TEST & SEM & CD \\
\hline Treat & 2 & 0.615 & 0.3077 & 1.9183 & 3.554 & NS & 0.1513 & NS \\
\hline Error & 18 & 2.888 & 0.1604 & & 2.989 & & & \\
\hline TOTAL & 20 & 3.503 & \multicolumn{7}{|c|}{ CV $\%=1.274$} \\
\hline
\end{tabular}

Table 4: ANOVA showing effect of forward speed on pod damage. 


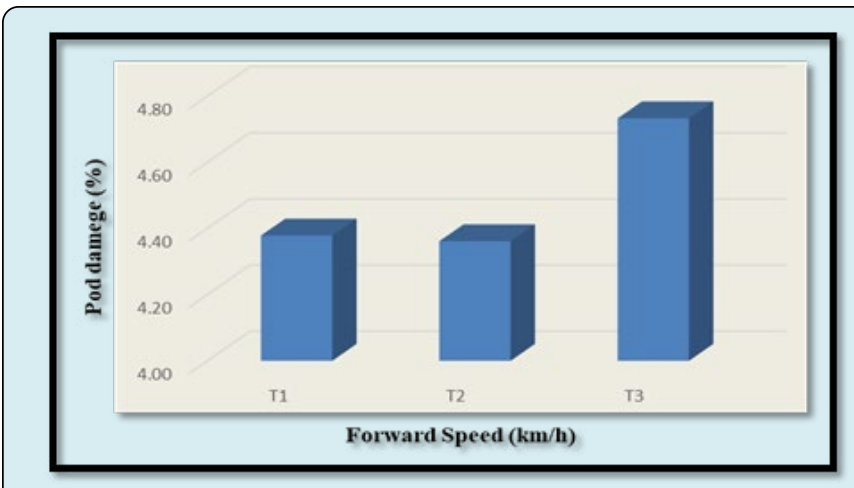

Figure 7: Graphical representation of pod damage percentage Vs forward speed.

\section{Cost Economics of Groundnut Digger Elevator cum Heap Formater}

The developed groundnut digger elevator cum heap formater was found to be operated at the cost of ₹ 371.98 per hour. Considering the custom hiring cost as $25 \%$ more than the operation cost, it was found to be ₹ 464.97 per hour. Average net annual benefit of machine was ₹ 27898.5. The payback period of machine was found 2.32 years. Benefit cost ratio of the machine was found 4.29. The cost of operation was calculated for the one who owns the mini tractor and machine. Total time required and cost of operation were $285.71 \mathrm{man}-\mathrm{h} / \mathrm{ha}$ and ₹ 8930 per ha for the manual harvesting method respectively.

\section{Summary and Conclusions}

The digging efficiency and the total quality of pod was found as 84.18, 85.23, $86.36176 .41,180.21$ and $173.91 \mathrm{gm}$ at forward speed of $1.5,2.0,2.5 \mathrm{~km} / \mathrm{h}$ respectively and field efficiency was 80.47. The best speed of developed groundnut digger elevator cum heap formatter was found $2.0 \mathrm{Km} / \mathrm{h}$. The cost of harvesting was found ₹ 371.98 per $h$ while The time required and cost of operation for manual harvesting of groundnut was $285.71 \mathrm{man}-\mathrm{h} / \mathrm{ha}$ and ₹ 8930 per ha. The economically comparison between manual and mechanical harvesting method to save $63.13 \%$ reduction in cost over manual harvesting.

\section{References}

1. Annual Report (2018) Ministry of Agriculture \& Farmers
Welfare, Govt of India.

2. Jakasania Ronak, Yadav Rajvir, Mohnot P (2018) Soiltool interaction using numerical methods-A review. Acta Science Agriculture (AGAS) 2(10): 67-70.

3. Stalker HT (1997) Peanut (Arachis hypogaea L.). Field Crops Research 53(1-3): 205-217.

4. Smyth MJ (1959) Drying and storage of peanuts in queens land. Department of Primary Industry, The peanut marketing board, Melbourn, pp: 50 .

5. Nautiyal PC, Bandyopadhyay AB, Zala PV (2001) In situ sprouting and regulation of fresh seed dormancy in spanish type groundnut. Field Crop Research 70(3): 233-241.

6. Afshin AM, Shamsollah A, Hossein NA, Mohammad MV (2014) Performance evaluation of a peanut harvesting machine in Guilan province. Iran International Journal of Biosciences 5(10): 94-101.

7. Mohanty DK, Das DK, Mohanty MK (2005) Performance evaluation of sweep type groundnut digger. Agricultural Engineering Today 29(3): 1-5.

8. Mishra J (2009) Development of a bullock drawn groundnut, (Arachis hypogaea L.) digger suitable for coastal Orissa. Journal of Oil Seeds Research 26(2): 187189.

9. Jaiswal H, Yadav R, Chavda D (2018) Development of mini tractor operated groundnut digger-cum-shaker. Jau, Junagdh, Krishikosh.

10. Gabir A, Ahmad Y (2001) Comparative study on different peanut digger blades. Agricultural Mechanical in Asia, Africa and Latin America 32(3): 43-45.

11. Vagadia VR, Bhutada S, Memon AH, Yadav R (2015) Development and testing of tractor drawn groundnut digger-shaker. AGRES: An International e-Journal 4(4): 53-64.

12. Mehta TD, Yadav Rajvir (2015) Development and performance evaluation of tractor operated onion harvester. AMA 46(4): 7-13.

13. Solanki HB, Yadav Rajvir (2009) Development and performance evaluation of tractor operated plant uprooter for castor crop. AMA 40(2): 41-46. 